\title{
Małgorzata Koszewska
}

Politechnika Łódzka

e-mail: malgorzata.koszewska@p.lodz.pl

\section{KONSUMENT WOBEC WYZWAŃ GOSPODARKI \\ O OBIEGU ZAMKNIECTYM - RYNEK TEKSTYLNO-ODZIEŻOWY}

\section{CONSUMER IN THE FACE OF THE CHALLENGES OF CIRCULAR ECONOMY IN TEXTILE AND CLOTHING MARKET}

DOI: $10.15611 /$ pn.2017.501.12

JEL Classification: D12

Streszczenie: Transformacja w kierunku gospodarki o obiegu zamkniętym (GOZ) wymaga istotnych zmian modeli produkcji i konsumpcji. Metody wprowadzania tych zmian będą odmienne w rożnych gałęziach przemysłu. Specyfika konkretnych branż wymaga więc indywidulnego podejścia i precyzyjnych analiz w ich obrębie. Celem niniejszego artykułu jest analiza roli konsumenta w transformacji przemysłu tekstylno-odzieżowego w kierunku GOZ, a w szczególności analiza czynników determinujących sposób postepowania konsumentów z niepotrzebną odzieżą. Badania ankietowe przeprowadzone na reprezentatywnej próbie dorosłych mieszkańców Polski pokazały, że sposób postępowania ze zużytą odzieżą istotnie różnicowały zmienne socjodemograficzne, takie jak płeć, wykształcenie, miejsce zamieszkania. Zależność ta była mniej widoczna w przypadku wieku.

Słowa kluczowe: gospodarka o obiegu zamkniętym, tekstylia, odzież, zachowania konsumpcyjne.

Summary: Transformation to a circular economy requires significant changes in production and consumption patterns. The methods of introducing these changes will be different in specific industries. The specificity of the industry requires a unique approach and precise analysis. The aim of the article is to analyze the role of a consumer in the transformation of textile and clothing industry towards circular economy. In particular, it aims to analyze the determinants of consumers' behavior with the unused clothing. The survey conducted on the representative sample of adults in Poland, showed that consumers' behavior in this area was significantly differentiated by sociodemographic variables such as sex, education and place of residence. The relationship was less apparent in the case of age.

Keywords: circular economy, textiles, clothing, consumer behavior. 


\section{Wstęp}

Zainteresowanie tematem gospodarki o obiegu zamkniętym (GOZ) w ostatnim czasie wyraźnie wzrasta, zarówno w kręgach naukowych, biznesowych, jak i rządowych. Obecny linearny model gospodarowania, opierający się na bezrefleksyjnej eksploatacji surowców naturalnych, wykorzystywanych, a następnie wyrzucanych, staje się bowiem coraz mniej pożądany w obliczu wyczerpywania się surowców, wzrostu i niestabilności ich cen, rosnącej zależności od dostawców z krajów trzecich oraz rosnącego zagrożenia równowagi ekologicznej i społecznej [Ministerstwo Rozwoju 2016]. Model GOZ zakłada zaś minimalizację ilości odpadów, ponowne wykorzystanie zawartych $w$ nich materiałów oraz jak najdłuższe zachowanie wartości produktów, materiałów oraz surowców. Wyzwania związane z transformacją w kierunku GOZ dotyczą każdego obszaru funkcjonowania współczesnych gospodarek, choć pojawiające się problemy i sposoby ich rozwiązania będą odmienne w różnych gałęziach przemysłu. Specyfika konkretnych branż wymaga więc indywidulnego podejścia i precyzyjnych analiz w ich obrębie.

Ograniczenia modelu gospodarki linearnej są szczególnie widoczne w przemyśle tekstylno-odzieżowym. Tekstylia i odzież, obok żywności, stanowią jedną z podstawowych grup towarów konsumpcyjnych, towarzyszą człowiekowi od chwili poczęcia do chwili śmierci, decydując w znacznym stopniu o jego samopoczuciu i zdrowiu. Od lat obserwujemy wzrost zapotrzebowania na stosunkowo tanią odzież, która użytkowana jest coraz krócej. To pociąga za sobą wzrost produkcji i rosnące zapotrzebowanie na tanie, łatwo dostępne surowce włókiennicze i rosnącą ilość odpadów tekstylnych.

Zmiana modelu funkcjonowania $\mathrm{z}$ liniowego na cyrkularny wymaga wiedzy, świadomości i zaangażowania wszystkich uczestników rynku: producentów, twórców technologii, konsumentów, ustawodawców. Szczególną rolę w tej transformacji będzie odgrywał konsument, który poprzez swoje wybory, liczbę i jakość kupowanych produktów, otwartość na nowe modele biznesowe oraz sposób postępowania ze zużytymi już produktami decydować będzie o szybkości i sukcesie planowanych zmian.

Celem artykułu jest analiza czynników determinujących sposób postępowania konsumentów ze zużytą odzieżą.

\section{Wyzwania gospodarki o obiegu zamkniętym w przemyśle tekstylno-odzieżowym}

Ograniczenia modelu gospodarki linearnej stają się coraz bardziej widoczne w przemyśle tekstylno-odzieżowym. Są one efektem współwystępowania szeregu czynników, z których znaczna część, w sposób bezpośredni lub pośredni, wynika z charakterystycznych dla krajów wysokorozwiniętych, mało racjonalnych wzorców konsumpcji. Fakt, iż wzorce te przejmowane są przez państwa dopiero wkraczające 
na ścieżkę szybkiego rozwoju gospodarczego, pozwala prognozować, że obserwowane obecnie problemy i zagrożenia będą z czasem narastać.
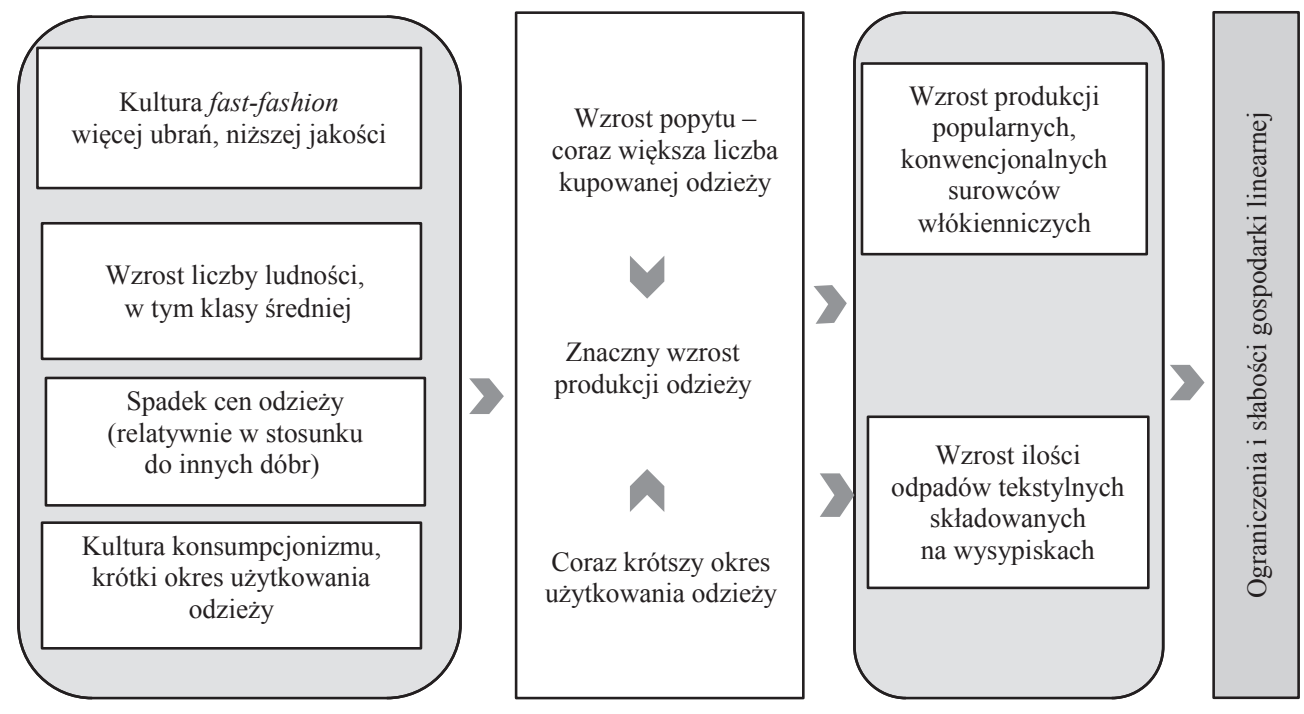

Rys. 1. Ograniczenia gospodarki linearnej w przemyśle tekstylno-odzieżowym

Źródło: opracowanie własne.

W przypadku przemysłu tekstylno-odzieżowego jako czynniki mające szczególnie istotny wpływ na obecną oraz przyszłą sytuację w kontekście GOZ należałoby wymienić kulturę fast fashion (szybkiej mody) i związany z nią konsumpcjonizm. Oba te trendy są następstwem dynamicznie zachodzących zmian po stronie zarówno produkcji, jak i konsumpcji. Model fast fashion to odpowiedź na rosnące tempo życia konsumentów, wzrost ich oczekiwań co do szybkości działania firm, szybkości dostaw, oferowania nowości w atrakcyjnych, przystępnych cenach. To także wyraz nowego atrakcyjnego modelu biznesowego, który przyczynił się do sukcesu wielu marek odzieżowych, modelu ukierunkowanego na jak najszybsze zaspokajanie bieżących potrzeb konsumenta, jednocześnie, w znacznym stopniu, bazującego na sztucznym ich kreowaniu, stymulowaniu popytu na produkty tzw. jednorazowego użytku, do natychmiastowej konsumpcji, modelu bazującego na często bezrefleksyjnej, ślepo podążającej za trendami konsumpcji [Sempruch-Krzemińska 2014; Wyman 2015].

Model fast fashion wymaga także istotnej redukcji kosztów pozwalającej na utrzymanie relatywnie niskich cen odzieży. Oczekiwany krótszy czas produkcji i szybsza dostawa to także konieczność, a jednocześnie możliwość zwiększania liczby kolekcji w skali roku. Zara oferuje 24 nowe kolekcje odzieży każdego roku, H\&M - od 12 do 16 i odświeża je co tydzień. Średnia liczba kolekcji europejskich 
firm odzieżowych wprowadzanych w skali roku wzrosła przeszło dwukrotnie, od dwóch w roku 2000 do około pięciu w roku 2011. W tym samym czasie obserwujemy spadek cen odzieży w stosunku do innych towarów konsumpcyjnych [Remy i in. 2016].

Czynniki te sprzyjają stałemu wzrostowi produkcji odzieży opartej na konwencjonalnych, stosunkowo tanich i łatwo dostępnych surowcach oraz stałemu wzrostowi konsumpcji. W ciągu ostatnich 14 lat liczba ubrań kupowanych przez przeciętnego konsumenta każdego roku wzrosła o $60 \%$, a globalna produkcja ubrań podwoiła się, co więcej, ubrania kupione 15 lat temu nosiliśmy dwa razy dłużej.

Nie należy jednak zapominać, że mimo szybszej produkcji i konsumpcji dóbr pozostają czynniki niezmienne - włókno nadal potrzebuje tej samej ilości czasu, żeby urosnąć (w przypadku bawełny - około roku), niezależnie od szybkości pojawiania się produktu na rynku, trudne do skrócenia są procesy czyszczenia, bielenia, barwienia. Przyspieszenie procesu produkcji i konsumpcji nie może obyć się bez wysokich kosztów środowiskowych i społecznych. Krótki czas wytwarzania tanich ubrań jest możliwy tylko dzięki eksploatacji siły roboczej oraz środowiska naturalnego [Fletcher 2007; Koszewska 2011].

Wszystkie wspomniane zjawiska powodują stały wzrost popytu, a w konsekwencji produkcji konwencjonalnych surowców włókienniczych oraz sprzyjają powstawaniu trudnych do efektywnego odzysku odpadów tekstylnych. Prognozowany wzrost liczby ludności w skali globalnej, w tym klasy średniej, dodatkowo sprzyjać będzie pogłębianiu się tych negatywnych zjawisk. Wszystko to wyraźnie wskazuje na konieczność zmiany współczesnych modeli produkcji i konsumpcji, przejścia z modelu linearnego w kierunku modelu gospodarki o obiegu zamkniętym (rys. 1).

W przypadku przemysłu tekstylno-odzieżowego, który charakteryzuje się szczególnie długim i globalnie rozproszonym łańcuchem produkcji, jest to wyzwanie wyjątkowo trudne. Wymagać będzie istotnych zmian modeli biznesowych firm odzieżowych. Kluczowy będzie etap projektowania produktu, od niego bowiem w znacznym stopniu zależeć będzie powodzenie zamykania obiegu w kolejnych fazach cyklu życia. To dobór surowca, konstrukcji, sposobu wykończenia decydować będzie bowiem o trwałości, uniwersalności, możliwości ponownego wykorzystania czy odzyskania surowca ze zużytego już produktu. Opłacalność i technologiczne możliwości recyklingu w znaczniej mierze uzależnione są od tego, na ile etap ten był brany pod uwagę w momencie opracowywania koncepcji produktu i jego projektowania.

Inną niezwykle ważną fazą jest etap zbiórki i sortowania zużytych ubrań; to on w znacznej mierze decydować będzie o tym, jak duży procent wartościowego surowca zostanie odzyskany z odpadów tekstylnych, a jaki trafi na wysypiska śmieci. Kluczowe dla wprowadzenia pozytywnych zmiany w tym obszarze (zwiększania odzysku surowca, a zmniejszania ilości odpadów na wysypiskach) będą systemy efektywnego sortowania odpadów tekstylnych oraz technologie pozwalające na odzysk surowca, biorąc po uwagę znaczne zróżnicowanie surowcowe wyrobów 
odzieżowych i tekstylnych (powszechne stosowanie mieszanek takich surowców, jak: celuloza, białko, polimery syntetyczne) oraz złożony charakter wyrobów (układy warstwowe, np. w przypadku odzieży sportowej, czy kompozyty tekstylne, np. w przypadku pokryć podłogowych).

Zmiany te warunkowane będą także sposobem postępowania z niepotrzebną lub/i zużytą odzieżą przez konsumentów. Dalsza część artykułu koncentrować będzie się na konsumencie i jego roli w transformacji przemysłu tekstylno-odzieżowego w kierunku GOZ; badania własne dotyczyć będą sposobu postępowania konsumentów polskich z niepotrzebną już odzieżą.

\section{Rola konsumenta w transformacji przemysłu tekstylno- -odzieżowego w kierunku gospodarki o obiegu zamkniętym}

Rola konsumenta we wspieraniu transformacji przemysłu tekstylno-odzieżowego w kierunku modelu o obiegu zamkniętym dotyczyć będzie kilku zasadniczych aspektów (rys. 2):

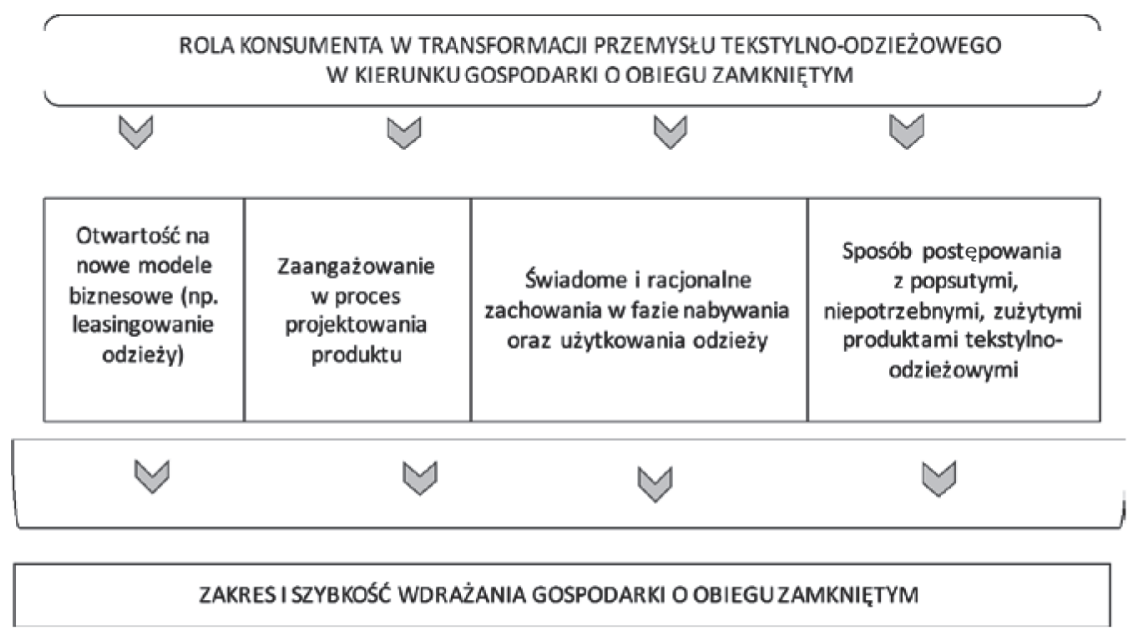

Rys. 2. Rola konsumenta w transformacji przemysłu tekstylno-odzieżowego w kierunku GOZ Źródło: opracowanie własne.

1. Otwartości na nowe modele biznesowe, zakładające m.in.: współużytkowanie produktów, kupowanie usługi użytkowania zamiast samego produktu (produkt-usługa, np. leasingowanie dżinsów zamiast ich zakupu) otwartość na innowacje, np. wykorzystanie druku 3D w przemyśle tekstylno-odzieżowym [Ellen MacArthur Foundation 2015]. 
2. Otwartości na współpracę $\mathrm{z}$ producentami, zaangażowania $\mathrm{w}$ proces projektowania i produkcji produktu (prosumpcja) z wykorzystaniem metod, takich jak: User Centered Design czy Design Thinking [Hannon i in. 2016].

3. Świadomych i racjonalnych zachowań w fazie nabywania oraz użytkowania produktu: skłonność przeciwstawienia się konsumpcjonizmowi - dekonsumpcja, racjonalizacja zakupów, uwzględnianie aspektów ekologicznych w czasie decyzji zakupowych, docenianie cech, takich jak trwałość, uniwersalność, modułowość, możliwość naprawienia, przedłużenia życia produktu, możliwość przyszłego recyklingu [Ellen MacArthur Foundation 2012].

4. Sposobu postępowania ze zużytymi, popsutymi lub niepotrzebnymi produktami tekstylno-odzieżowymi oraz chęci ograniczania ilości odpadów tekstylnych generowanych $w$ gospodarstwie domowym.

$\mathrm{Z}$ punktu widzenia konsumenta i jego roli w transformacji w kierunku GOZ kluczowe są odpady tekstylne powstające w fazie konsumpcji, generowane przez użytkowników, takie jak zużyta odzież oraz tekstylia do użytku domowego (takie jak: pościel, ręczniki, dywany, zasłony, obicia kanapowe itp.) możemy przyjąć, że ta grupa odpadów mieści się w kategorii odpadów komunalnych.

Niezwykle istotne wydają się więc badania mające na celu analizę czynników determinujących sposób zachowania konsumenta w obszarach kluczowych dla rozwoju modelu gospodarki o obiegu zamkniętym w Polsce.

\section{Cel, hipotezy badawcze oraz metoda badań własnych}

Celem analizy była identyfikacja czynników determinujących zachowania konsumentów w jednym z kluczowych z punktu widzenia gospodarki o obiegu zamkniętym obszarze zachowań konsumentów, tzn. postepowaniu z odzieżą po jej użyciu. Analizowano zróżnicowanie zachowań w zależności od wybranych zmiennych socjodemograficznych (takich jak: płeć, wiek, wykształcenie, miejsce zamieszkania) oraz w zależności od zwyczajów zakupowych respondentów. Postawiono następujące hipotezy badawcze:

- H1: płeć istotnie różnicuje sposób postępowania z niepotrzebną odzieżą.

- H2: wiek istotnie różnicuje sposób postępowania z niepotrzebną odzieżą.

- H3: wykształcenie istotnie różnicuje sposób postępowania z niepotrzebną odzieżą.

- H4: miejsce zamieszkania istotnie różnicuje sposób postępowania z niepotrzebną odzieżą.

- H5: kryteria wyboru odzieży oraz zwyczaje zakupowe istotnie różnicują sposób postępowania z niepotrzebną odzieżą.

Badanie przeprowadzono na liczącej 981 osób próbie losowej dorosłych mieszkańców Polski (przełom lat 2010/2011). Próba została wylosowana z systemu PESEL. Wywiady zrealizowano metodą face-to-face przy zastosowaniu CAPI (Computer Assisted Personal Interviewing). Strukturę badanej populacji przedstawia tab. 1. 
Do analizy uzyskanych wyników zastosowano tabele krzyżowych oraz test chi-kwadrat. W celu wyodrębnienia typów konsumentów ze względu na ich zwyczaje zakupowe i kryteria wyboru odzieży zastosowano analizę skupień k-średnich.

Tabela 1. Struktura społeczno-demograficzna badanych

\begin{tabular}{|l|l|c|}
\hline \multicolumn{2}{|l|}{ Wyszczególnienie } & \% z N w kolumnie \\
\hline \multirow{4}{*}{ Płeć } & mężczyzna & 47,6 \\
\cline { 2 - 3 } & kobieta & 52,4 \\
\hline \multirow{5}{*}{ Miejsce zamieszkania } & $18-24$ lata & 13,6 \\
\cline { 2 - 3 } & $25-34$ & 17,4 \\
\cline { 2 - 3 } & $35-44$ & 14,6 \\
\cline { 2 - 3 } & $45-54$ & 18,1 \\
\cline { 2 - 3 } & 55-64 & 18,1 \\
\cline { 2 - 3 } & w5 lat i więcej & 18,3 \\
\cline { 2 - 3 } & miasto do 20 tys. & 37,6 \\
\cline { 2 - 3 } & $20-100$ tys. & 13,9 \\
\cline { 2 - 3 } & $101-500$ tys. & 20,0 \\
\cline { 2 - 3 } & 501 tys. i więcej mieszk. & 15,8 \\
\hline \multirow{5}{*}{ Wykształcenie } & podstawowe & 12,7 \\
\cline { 2 - 3 } & zasadnicze zawodowe & 25,3 \\
\cline { 2 - 3 } & średnie & 33,7 \\
\cline { 2 - 3 } & wyższe & 15,3 \\
\hline
\end{tabular}

Źródło: obliczenia własne z użyciem oprogramowania IBM SPSS.

\section{Wyniki badań własnych}

Przeprowadzona analiza pozwoliła stwierdzić, że na poziomie deklaratywnym konsumenci w Polsce postępują dość racjonalnie ze zużytą odzieżą. W zdecydowanej większości (ponad 60\%) deklarują, że przekazują ją rodzinie, znajomym lub organizacjom charytatywnym, np. PCK, 16\% respondentów przechowuje już zużytą odzież w domu, a jedynie $8 \%$ wyrzuca ją do śmieci. Deklarowane przez respondentów zachowania pozwalają wnioskować, że w zdecydowanej większości odzież, która nie jest już potrzebna, pozostaje jeszcze przez jakiś czas w obiegu, co należy ocenić pozytywnie.

Analiza rozkładu odpowiedzi oraz wyniki testu chi-kwadrat $(p<0,005)$ wykazały, że sposób postępowania ze zużytą odzieżą zależy od płci, wykształcenia oraz miejsca zamieszkania respondentów, nie zależy natomiast w sposób istotny staty- 


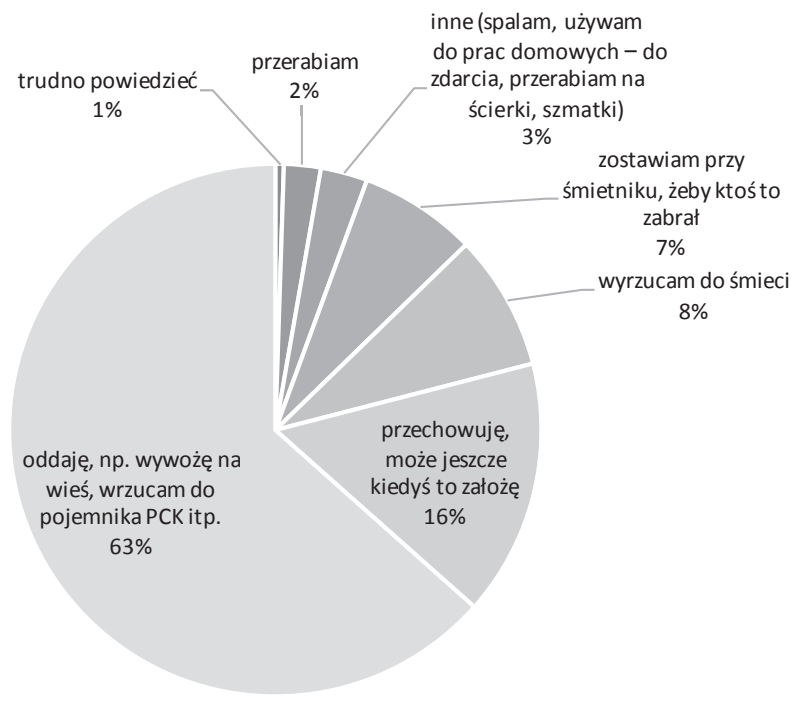

Rys. 3. Sposób postępowania z odzieżą, której respondenci nie zamierzają dłużej nosić Źródło: opracowanie własne z użyciem oprogramowania IBM SPSS [Koszewska 2018].

stycznie od wieku respondentów. Badanie pozwoliło więc na pozytywną weryfikację hipotez H1, H3 oraz H4. Kobiety zdecydowanie częściej niż mężczyźni oddawały niepotrzebne już ubrania znajomym, rodzinie czy organizacjom charytatywnym. Jednocześnie zdecydowanie rzadziej wyrzucały niepotrzebną odzież do śmieci (rys. 4).

oddaję, np. wywożę na wieś, wrzucam do pojemnika PCK itp.

$$
\begin{aligned}
& \text { przechowuję, może jeszcze kiedyś to założę } \\
& \text { zostawiam przy śmietniku, żeby ktoś to zabrał } \\
& \text { wyrzucam do śmieci } \\
& \text { inne (spalam, używam do prac domowych - do zdarcia, } \\
& \text { przerabiam na ścierki, szmatki) }
\end{aligned}
$$
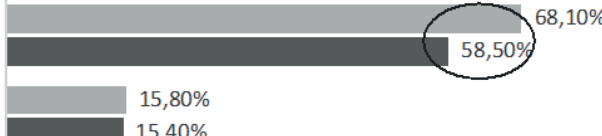

$15,40 \%$

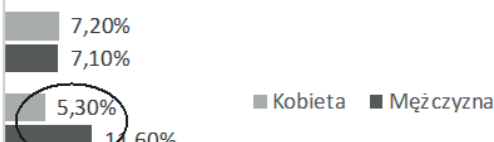

$2,10 \%$

$3,40 \%$

$$
\begin{array}{l|c}
\text { przerabiam } & 1,60 \% \\
3,00 \%
\end{array}
$$

Rys. 4. Sposób postępowania z odzieżą, której respondenci nie zamierzają dłużej nosić w zależności od płci

Źródło: obliczenia własne z użyciem oprogramowania IBM SPSS [Koszewska 2018 ]. 
Osoby z wyższym wyksztalceniem zdecydowanie rzadziej wyrzucały niepotrzebną odzież do śmieci, częściej zaś oddawały ją rodzinie, znajomym czy organizacjom charytatywnym (tab. 2, rys. 5).

Tabela 2. Sposób postępowania z odzieżą, której respondenci nie zamierzają dłużej nosić, w zależności od wykształcenia [\%]

\begin{tabular}{|l|c|c|c|c|c|}
\hline \multirow{2}{*}{ Wyszczególnienie } & \multicolumn{4}{|c|}{ Wykształcenie } & \multirow{2}{*}{ Ogółem } \\
\cline { 2 - 5 } & podstawowe & $\begin{array}{r}\text { zasadnicze } \\
\text { zawodowe }\end{array}$ & średnie & wyższe & \\
\hline $\begin{array}{l}\text { Inne (spalam, używam do prac } \\
\text { domowych - do zdarcia, przerabiam na } \\
\text { ścieki, szmatki) }\end{array}$ & 4,0 & 7,1 & 9,7 & 6,6 & 7,1 \\
\hline $\begin{array}{l}\text { Oddaję, np. wywożę na wieś, wrzucam } \\
\text { do pojemnika PCK itp. }\end{array}$ & 53,8 & 59,3 & 67,1 & 77,5 & 63,3 \\
\hline $\begin{array}{l}\text { Przechowuję, może jeszcze kiedyś to } \\
\text { założę }\end{array}$ & 17,7 & 18,6 & 15,4 & 7,9 & 15,7 \\
\hline Przerabiam & 5,6 & 1,2 & 0,9 & 1,3 & 2,2 \\
\hline Wyrzucam do śmieci & 13,7 & 9,5 & 5,1 & 4,6 & 8,3 \\
\hline Coś innego & 4,4 & 3,6 & 1,8 & 1,3 & 2,8 \\
\hline Trudno powiedzieć & 0,8 & 0,8 & 0,0 & 0,7 & 0,5 \\
\hline
\end{tabular}

Źródło: obliczenia własne z użyciem oprogramowania IBM SPSS [Koszewska 2018].
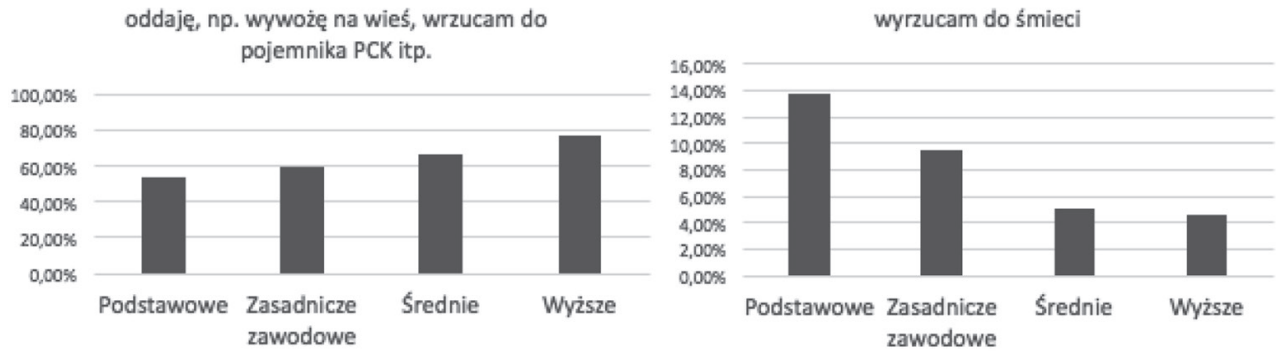

Rys. 5. Sposób postępowania z odzieżą, której respondenci nie zamierzają dłużej nosić, w zależności od wykształcenia

Źródło: obliczenia własne z użyciem oprogramowania IBM SPSS [Koszewska 2018].

Mieszkańcy wsi częściej niż mieszkańcy dużych miast wyrzucali niepotrzebną odzież do śmieci, przechowywali z myślą ponownego użycia w przyszłości oraz przerabiali, rzadziej natomiast oddawali znajomym lub wrzucali do pojemnika PCK (tab. 3).

Wyniki testu chi-kwadrat nie pozwoliły natomiast na pozytywną weryfikację hipotezy o statystycznie istotnej zależności między sposobem postępowania z niepo- 
Tabela 3. Sposób postępowania z odzieżą, której respondenci nie zamierzają dłużej nosić, w zależności od miejsca zamieszkania [\%]

\begin{tabular}{|l|c|c|c|c|c|c|}
\hline \multicolumn{1}{|c|}{ Wyszczególnienie } & Wieś & $\begin{array}{c}\text { Miasto do } \\
20 \text { tys. }\end{array}$ & $\begin{array}{c}20-100 \\
\text { tys. }\end{array}$ & $\begin{array}{c}101-500 \\
\text { tys. }\end{array}$ & $\begin{array}{c}\text { 501 tys. } \\
\text { i więcej } \\
\text { mieszk. }\end{array}$ & Ogółem \\
\hline $\begin{array}{l}\text { Zostawiam przy śmietniku, żeby } \\
\text { ktoś to zabrał }\end{array}$ & 4,3 & 3,6 & 10,7 & 9,7 & 11,3 & 7,2 \\
\hline $\begin{array}{l}\text { Oddaję, np. wywożę na wieś, } \\
\text { wrzucam do pojemnika PCK itp. }\end{array}$ & 49,6 & 70,8 & 67,3 & 76,8 & 73,4 & 63,4 \\
\hline $\begin{array}{l}\text { Przechowuję, może jeszcze kiedyś } \\
\text { to założę }\end{array}$ & 22,8 & 16,8 & 10,7 & 8,4 & 8,9 & 15,5 \\
\hline Przerabiam & 4,1 & 1,5 & 0,5 & 0,6 & 2,4 & 2,2 \\
\hline Wyrzucam do śmieci & 13,0 & 6,6 & 8,2 & 4,5 & 1,6 & 8,4 \\
\hline Coś innego* & 4,9 & 0,7 & 2,6 & 0,0 & 2,4 & 2,8 \\
\hline Trudno powiedzieć & 1,4 & 0,0 & 0,0 & 0,0 & 0,0 & 0,5 \\
\hline
\end{tabular}

* Najczęstsze odpowiedzi: spalam, używam do prac domowych - do zdarcia, przerabiam na ścierki szmatki, sprzedaję.

Źródło: obliczenia własne z użyciem oprogramowania IBM SPSS [Koszewska 2018].

Tabela 4. Sposób postępowania z odzieżą, której respondenci nie zamierzają dłużej nosić, w zależności od wieku [\%]

\begin{tabular}{|l|r|r|r|r|r|r|c|}
\hline \multicolumn{1}{|c|}{ Wyszczególnienie } & $\begin{array}{c}18-24 \\
\text { lata }\end{array}$ & $25-34$ & $35-44$ & $45-54$ & $55-64$ & $\begin{array}{c}65 \text { lat } \\
\text { i więcej }\end{array}$ & Ogólem \\
\hline $\begin{array}{l}\text { Zostawiam przy śmietniku, żeby ktoś } \\
\text { to zabrał }\end{array}$ & 3,8 & 7,6 & 7,0 & 7,9 & 8,5 & 6,1 & 6,9 \\
\hline $\begin{array}{l}\text { Oddaję, np. wywożę na wieś, } \\
\text { wrzucam do pojemnika PCK itp. }\end{array}$ & 64,7 & 65,9 & 69,9 & 61,6 & 66,7 & 53,9 & 63,5 \\
\hline $\begin{array}{l}\text { Przechowuję, może jeszcze kiedyś to } \\
\text { założę }\end{array}$ & 17,3 & 17,1 & 12,6 & 13,6 & 13,0 & 20,0 & 15,6 \\
\hline Przerabiam & 1,5 & 2,9 & 0,0 & 3,4 & 0,6 & 4,4 & 2,2 \\
\hline Wyrzucam do śmieci & 9,8 & 4,7 & 8,4 & 9,0 & 8,5 & 10,0 & 8,4 \\
\hline Coś innego* & 3,0 & 1,2 & 2,1 & 4,5 & 1,7 & 4,4 & 2,9 \\
\hline Trudno powiedzieć & 0,0 & 0,6 & 0,0 & 0,0 & 1,1 & 1,1 & 0,5 \\
\hline
\end{tabular}

* Najczęstsze odpowiedzi: spalam, używam do prac domowych - do zdarcia, przerabiam na ścierki szmatki, sprzedaję.

Źródło: obliczenia własne z użyciem oprogramowania IBM SPSS [Koszewska 2018] .

trzebną już odzieżą a wiekiem respondentów. Analiza rozkładu odpowiedzi pozwala jednak stwierdzić, że osoby starsze (65+) częściej niż pozostałe grupy wiekowe przechowywały niepotrzebną odzież z myślą o jej ponownym wykorzystaniu oraz 
przerabiały ją. Rzadziej natomiast oddawały rodzinie, znajomym czy organizacjom charytatywnym.

W celu weryfikacji hipotezy H5, dotyczącej wpływu zwyczajów zakupowych i kryteriów wyboru na sposób postępowania z niepotrzebną odzieżą, analizowano zróżnicowanie tych zachowań w wyodrębnionych grupach typologicznych [Koszewska 2013]. Rysunek 6 przedstawia charakterystykę oraz udział poszczególnych grup typologicznych w badanej populacji.

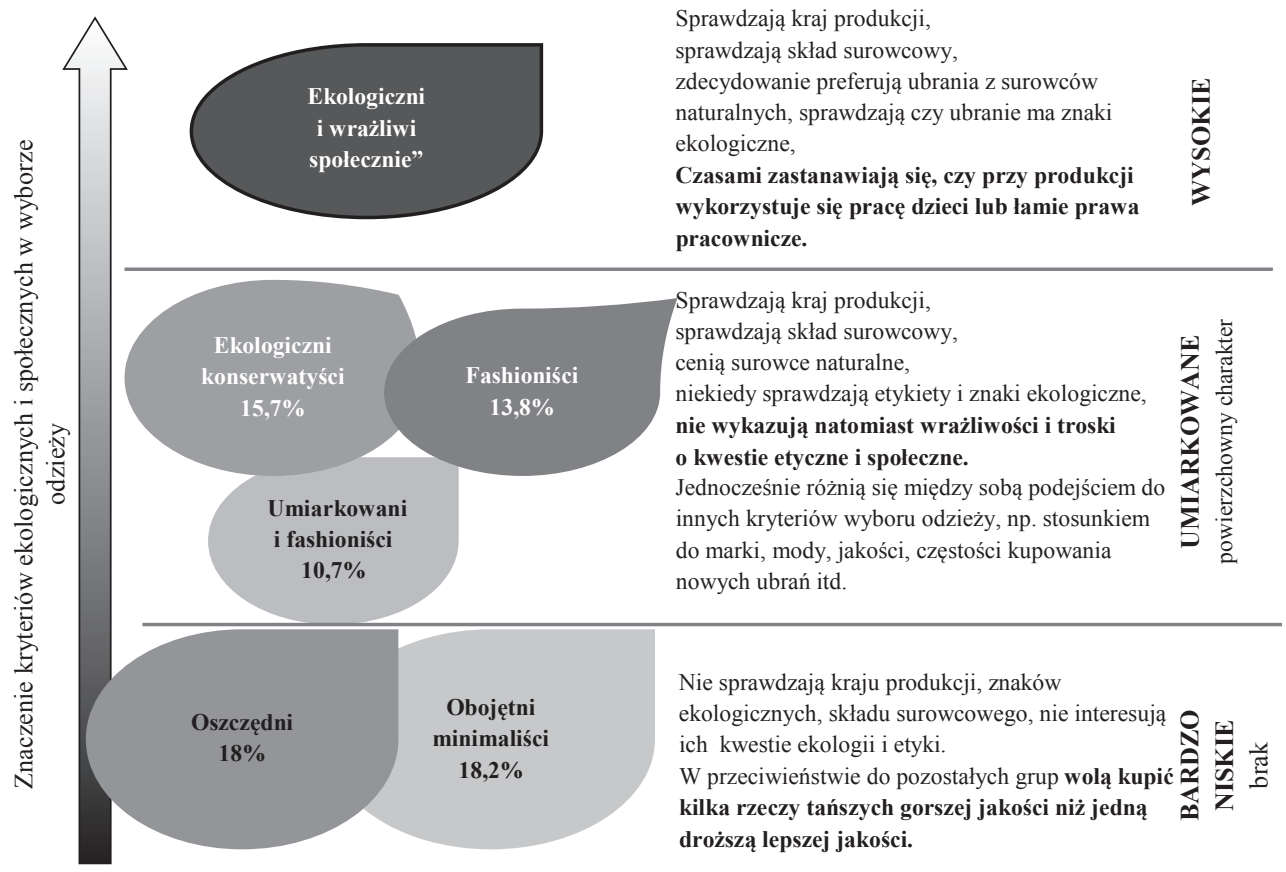

Rys. 6. Typologia konsumentów ze względu na stosowane kryteria wyboru odzieży oraz zwyczaje zakupowe

Źródło: [Koszewska 2013].

Wyniki testu chi-kwadrat $(p<0,005)$ i analiza rozkładu odpowiedzi wykazały, iż sposób postępowania z nieużywaną już odzieżą w istotny sposób zależy od zwyczajów zakupowych konsumentów i kryteriów, którymi kierują się w fazie nabywczej. Hipoteza H5 została więc pozytywnie zweryfikowana (rys. 7).

Grupy, dla których kwestie ekologii i etyki nie mają dużego znaczenia w fazie nabywania odzieży, częściej deklarowały zachowania mniej pożądane z punktu widzenia GOZ, takie jak wyrzucanie niepotrzebnej odzieży na śmieci czy przechowywanie $\mathrm{w}$ domu. Rzadziej zaś oddawały taką odzież osobom potrzebującym lub organizacjom, które zajmują się efektywnym jej zagospodarowaniem. 
oddaję, np. wywożę na wieś, wrzucam do pojemnika PCK itp.

przechowuję, może jeszcze kiedyś to założę

zostawiam przy śmietniku, żeby ktoś to zabrał

wyrzucam do śmieci

przerabiam

\begin{tabular}{|lr|r|}
\hline oszczędny & 0,616 \\
\hline obojętny minimalista & 0,461 & \\
\hline umiarkowany fashionista & 0,571 & 0,742 \\
\hline fashionista & & 0,703 \\
\hline ekologiczny konserwatysta & 0,75 \\
\hline
\end{tabular}

0,141

0,233 obojętny minimalista

0,162 umiarkowany fashionista

0,135 fashionista

0,135 ekologiczny konserwatysta

0,112 ekologiczny i wrażliwy społ.

0,056 oszczędny

0,083 obojętny minimalista

0,086 umiarkowany fashionista

0,071 fashionista

0,058 ekologiczny konserwatysta

0,075 ekologiczny i wrażliwy społ.

0,073 oszczędny

0,133 obojętny minimalista

0,143 umiarkowany fashionista

0,026 fashionista

0,077 ekologiczny konserwatysta

0,05 ekologiczny i wrażliwy społ.

0,028 oszczędny

0,061 obojętny minimalista

coś innego 0,038 umiarkowany fashionista

0,013 fashionista

0,019 ekologiczny konserwatysta

0,006 ekologiczny i wrażliwy społ.

0,085 oszczędny

0,017 obojętny minimalista

umiarkowany fashionista

0,013 fashionista

0,006 ekologiczny konserwatysta

0,006 ekologiczny i wrażliwy społ.

Rys. 7. Zróżnicowanie zachowań w obszarze postępowania z niepotrzebną odzieżą w wyodrębnionych grupach typologicznych

Źródło: obliczenia własne z użyciem oprogramowania IBM SPSS [Koszewska 2018].

Do ciekawych wniosków prowadzić może analiza odpowiedzi na pytanie dotyczące przerabiania niepotrzebnej odzieży. Zdecydowanie najczęściej czyniła tak grupa konsumentów oszczędnych, co może wskazywać, że chęć przerabiania odzieży w celu dłuższego jej użytkowania wynika nie tyle z większej wiedzy i świadomości ekologicznej, ile raczej z pobudek ekonomicznych. 


\section{Zakończenie}

Badania ankietowe przeprowadzone na reprezentatywnej próbie dorosłych mieszkańców Polski pokazały, że sposób postępowania ze zużytą odzieżą istotnie różnicowały zmienne socjodemograficzne, takie jak płeć, wykształcenie, miejsce zamieszkania. Zależność ta była mniej widoczna w przypadku wieku. Z kolei badania z 2015 roku dotyczące innego obszaru zachowań konsumentów istotnego dla GOZ, tzn. skłonności do konsumpcjonizmu', wskazały, że zależy on przede wszystkim właśnie od wieku respondentów, w niewielkim zaś stopniu od płci i wykształcenia [Koszewska 2017]. Ostanie badania dotyczące rozumienia pojęcia GOZ i akceptacji jej założeń wskazały natomiast na zależność badanych zjawisk od płci i miejsca zamieszkania. Kobiety oraz mieszkańcy większych miast lepiej rozumieli założenia zrównoważonego rozwoju i GOZ [Kulczycka i in. 2017].

Można więc wnioskować, że zmienne socjodemograficzne różnicują zachowania konsumentów w obszarze GOZ, choć rodzaj i zakres ich oddziaływania może być odmienny w przypadku różnych aspektów zachowań konsumentów, jak i różnych grup produktowych.

Przeprowadzona analiza potwierdziła także, że istotnym czynnikiem determinującym zachowania w tym obszarze są zwyczaje zakupowe konsumentów oraz kryteria, jakimi kierują się oni przy wyborze odzieży.

Należy jednak podkreślić, że obecnie, zwłaszcza w Polsce, jest bardzo ograniczona liczba badań dotyczących zachowań konsumentów w obszarach związanych ze wdrażaniem modelu GOZ. Te istniejące opierają się jedynie na wybranych aspektach zachowań, obejmują tylko część populacji konsumentów polskich lub wymagają aktualizacji. Przeprowadzona w artykule analiza dotyczy zachowań konsumentów na przełomie lat 2010 i 2011 i dotyka jedynie jednego $\mathrm{z}$ wielu istotnych obszarów, tzn. sposobu postępowania z odzieżą, której konsumenci już nie zamierzają używać. W celu potwierdzenia uzyskanych wniosków oraz uchwycenia ewentualnych zmian wskazane byłoby więc powtórzenie badań w bardziej kompleksowym ujęciu.

\section{Literatura}

Ellen MacArthur Foundation, 2012, Towards The Circular Economy, Opportunities for the Consumer Goods Sector.

Ellen MacArthur Foundation, 2015, Delivering the circular economy, a toolkit for policymakers. Fletcher K., 2007, Slow fashion, Ecologist, http://www.theecologist.org (31.10.2017).

\footnotetext{
${ }^{1}$ Przejawiającego się zachowaniami, takimi jak: kupowanie produktów bez faktycznej potrzeby ich posiadania, kupowanie dla samej przyjemności, skłonność do ulegania przecenom i obniżkom, kupowanie produktów rzadko potem używanych.
} 
Hannon E., Kuhlmann M., Thaidigsmann B., 2016, Developing products for a Circular Economy. Cross-Functional Collaboration and Customer-Focused Design Thinking Can Help Companies Reap More Value from the Energy and Resources they Use, McKinsey \& Company.

Kochan R., Wojnarowska M. (red.), Towaroznawstwo w badaniach i praktyce - Ekologiczne, ekonomiczno-prawne i marketingowe aspekty jakości produktów, Polskie Towarzystwo Towaroznawcze, Kraków.

Koszewska M., 2011, Social and Eco-labelling of textile and clothing goods as means of communication and product differentiation, Fibres \& Textiles in Eastern Europe, 19(4), s. 20-26.

Koszewska M., 2013, A typology of Polish consumers and their behaviours in the market for sustainable textiles and clothing, International Journal of Consumer Studies, 37(5), s. 507-521.

Koszewska M., 2017, Rola konsumenta w tworzeniu gospodarki o obiegu zamkniętym, w Salerno-

Koszewska M., 2018, Circular Economy in Textiles and Fashion - The Role of a Consumer, [w:] Circular Economy in Textiles and Apparel, red. S.S. Muthu, Series: The Textile Institute Book Series Woodhead Publishing- Elsevier. (w druku)

Kulczycka J., Nowaczek A., Smol M., Avdiushchenko A., Hausner J., 2017, Gospodarka o obiegu zamkniętym - znajomość i akceptacja założeń wśród mieszkańców Matopolski. Aura nr 10.

Ministerstwo Rozwoju, 2016, Mapa drogowa transformacji w kierunku gospodarki o obiegu zamkniętym, Konspekt do prac Zespołu do spraw Gospodarki o Obiegu Zamkniętym.

Remy N., Speelman E., Swartz S., 2016, Style that's Sustainable: A New Fast-Fashion Formula, McKinsey \& Company.

Sempruch-Krzemińska K., 2014, Fast fashion — przyszłość branży mody? Fast fashion - future of fashion industry?, Marketing i Rynek, nr 2, s. 25-31.

Wyman O., 2015, Fast fashion. Staying On-Trend with a New Style of Supply Chain, www.oliverwyman.com (31.10.2017). 